\title{
Relations between mud volcanoes, thrust deformation, slope sedimentation, and gas hydrate, offshore north Panama
}

\author{
Donald L. Reed, E. A. Silver and J. E. Tagudin \\ Earth Sciences Board and Institute of Marine Sciences, University of California, Santa \\ Cruz, California 95064, USA
}

and T. H. Shipley

Institute for Geophysics, University of Texas, Austin, Texas 78751, USA

\author{
and $P$. Vrolijk \\ Department of Geological Sciences, University of Michigan, Ann Arbor, Michigan \\ 48109, USA
}

Received 1 April 1989; accepted 1 September 1989

\begin{abstract}
SeaMARC II swath-mapping and migrated seismic reflection data show a high concentration of mud volcanoes in the primary sediment depocentre along the lower slope of a thrust belt, offshore north Panama. The mud volcanoes are $0.4-2.0 \mathrm{~km}$ wide, $<100 \mathrm{~m}$ high, and have pierced the crests of dominantly seaward-verging, thrust-bounded anticlines, landward of the frontal fold. The depocentre marks the confluence of the two major sediment transport systems along the northern Panama margin. Few mud volcanoes are located outside of the depocentre, except in a mid-slope region slightly east of the depocentre and near a zone of probable strike-slip deformation.

Sonar reflectivity (backscattering), sediment cores, and seismic stratigraphic relations indicate that the depocentre contains thick sequences of basinal turbidites which are ponded between the anticlinal ridges. The ridges are composed of the deformed turbidites of the Colombian basin and exhibit a strong bottom-simulating reflector (BSR), apparently associated with a gas hydrate layer. Based on the concentration of mud volcanoes along the crests of the anticlinal ridges in the depocentre and the structural position of the BSR, we suggest that folding along the deformation front, sediment ponding leading to differential loading, methane migration and accumulation in the anticlines, and gas hydrate formation are important factors in the development of mud volcanoes in this region.
\end{abstract}

Keywords: mud volcanoes; submarine thrust belt; offshore Panama

\section{Introduction}

Mud volcanoes and shale diapirs have been described from a wide variety of tectonic environments, including passive contintental margins (Hedberg, 1980) and continental interiors (Fertl, 1976), as well as transform (Higgins and Saunders, 1967) and convergent plate boundaries (Stride et al. 1982). In the latter setting, the structural position of mud volcanoes has been fundamental to models relating sediment deformation to high pore fluid pressures within and along the base of accretionary prisms (Westbrook and Smith, 1983). Furthermore. mud volcanoes and diapirs have been suggested as a means of generating the deformed melanges which characterize ancient subduction complexes (Williams et al., 1984; Barber et al., 1986).

Several studies have examined individual volcanoes or mud ridges seaward of the deformation front in submarine accretionary prisms (Westbrook and Smith. 1983; Breen et al., 1986; Langseth et al., 1988). Brown and Westbrook (1988) combined GLORIA side-scan sonographs with multichannel seismic data to map the

0264-8172/90/010044-11\$03.00

1990 Butterworth \& Co. (Publishers) Ltd distribution of mud volcanoes along the Barbados Ridge Complex of the Lesser Antilles forearc. We use SeaMARC II and 57 migrated reflection profiles to examine the distribution of mud volcanoes in another region of lithospheric convergence, a submarine thrust belt along northern Panama (Figure 1). Although we use the term "mud volcano", direct observations and bottom samples are not available at this time. Our analysis is based on sonar images of features which have breached the sea floor and are therefore inferred to represent sites of extruded sediment, fluids. or gas. These features may be analogous to the mud volcanoes and diapirs that have been described in the nearby offshore and onshore regions of Colombia (Shepard, 1973; Hedberg, 1980).

The distribution of mud volcanoes is compared to the location of the principal structural features and sedimentary deposits in the thrust belt. We then examine the possible consequences of fold-thrust formation on the development of the mud volcanoes. These processes can generate mud volcanoes by themselves (Hedberg, 1974; 1980) or produce a 

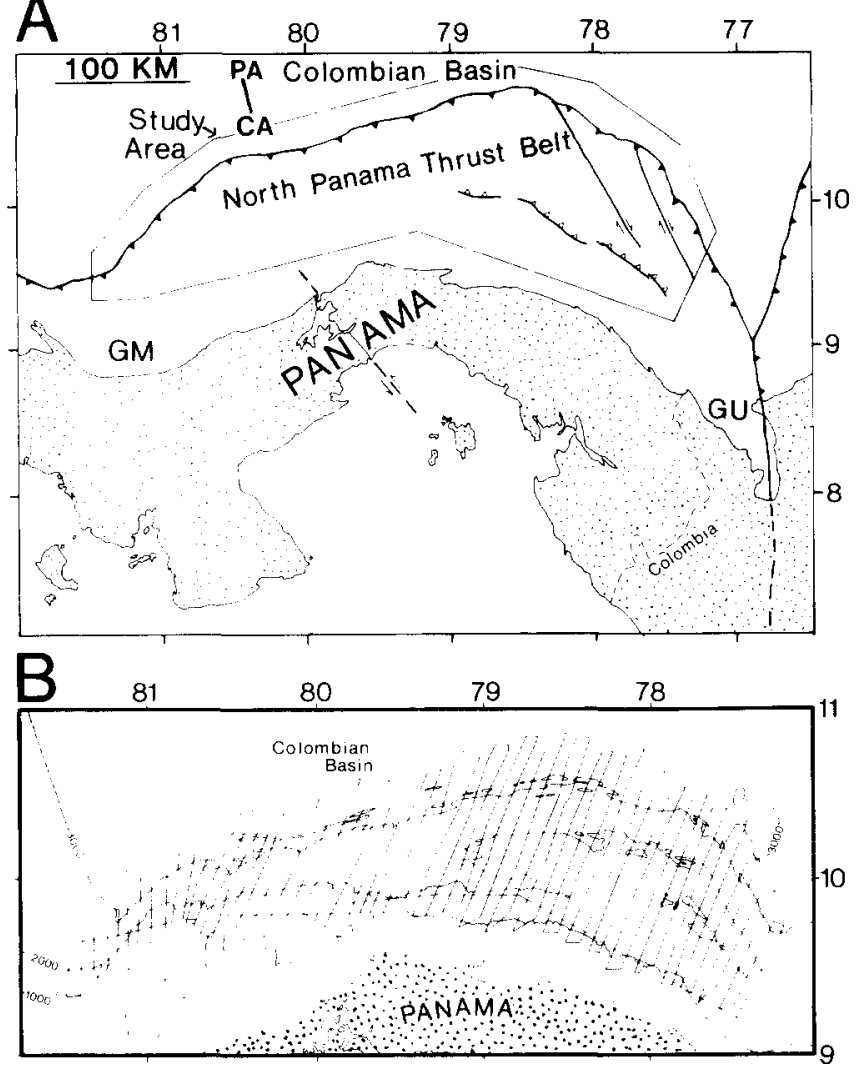

Figure 1 (A) General map of the north Panama thrust belt and surrounding regions, modified from Case and Holcombe (1980). Study area outlined. GU, Gulf of Uraba; GM, Gulfo de los Mosquitos; PA-CA, relative plate motion between Caribbean and Panama plates from Silver et al. (1990). (B) Track chart of SeaMARC II data and 57 migrated reflection profiles
Mud volcanoes offshore north Panama: D. L. Reed et al. triggering event for mud eruptions related to diapiric intrusions (Breen et al., 1988).

\section{Data acquisition and processing}

Approximately $47000 \mathrm{~km}^{2}$ of the northern Panama margin were surveyed with the SeaMARC II and digital seismic reflection systems aboard the $\mathrm{R} / \mathrm{V}$ Moana Wave of the Hawaii Institute of Geophysics (HIG). High resolution SeaMARC II side-scan sonar and bathymetric data were merged into a continuous map that is traversed every $7-10 \mathrm{~km}$ by a seismic reflection profile (Figure IB). Colour-coded bathymetry was hand-contoured at $100 \mathrm{~m}$, compared with computer-contoured plots, and overlain on the side-scan sonar map. Side-scan sonographs were used to interpolate water depths between adjacent swaths of SeaMARC bathymetry.

Single-channel digital reflection data were processed through deconvolution, time-varying bandpass filter, automatic gain control (AGC), and finite-difference $\left(45^{\circ}\right)$ migration. Reflectivity of the side-scan sonar data and shallow seismic stratigraphic relations were integrated with descriptions of seven piston cores (Figure 2; Table 1), obtained from the National Geophysical Data Center (NGDC). The cores range in length from 36 to $850 \mathrm{~cm}$.

\section{Regional setting}

The northern margin of Panama is composed of a wide belt of deformed strata (Bowin. 1976; Case and Holcombe, 1980), hereafter referred to as the north Panama thrust belt (NPTB) (Figure 1). The onset of thrusting is poorly known, but probably coincided with

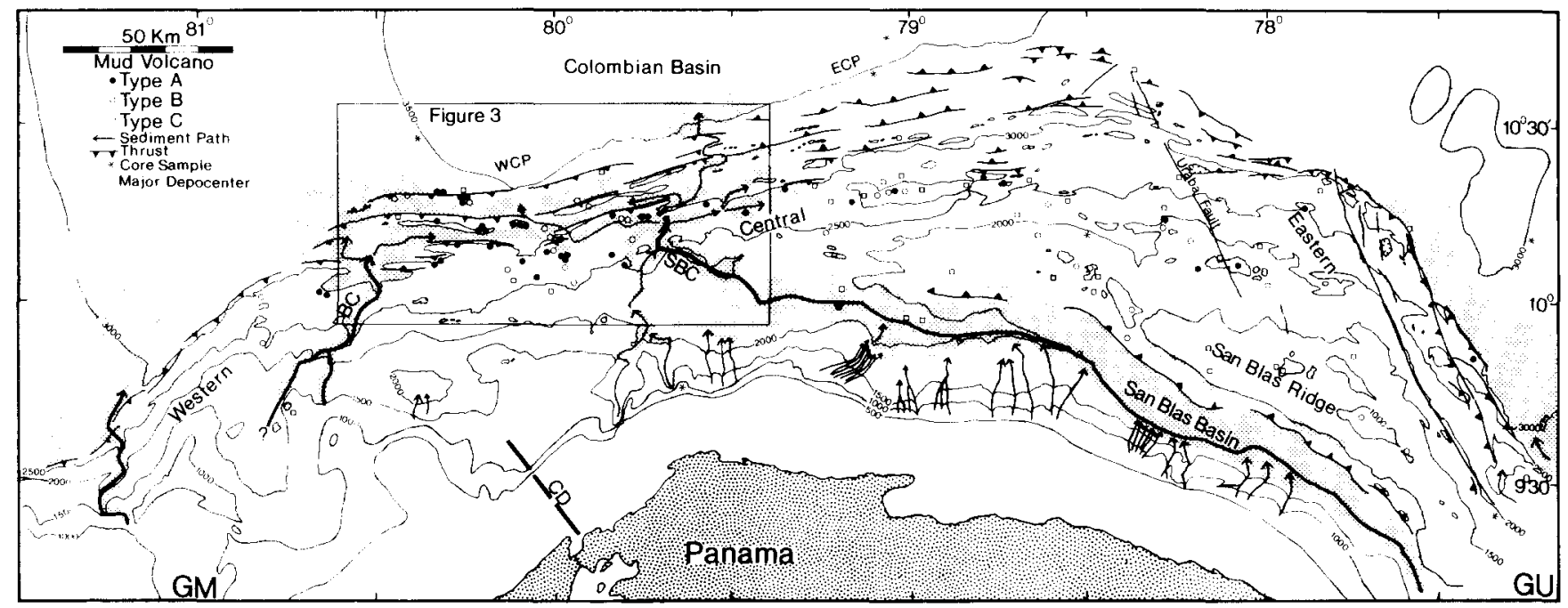

Figure 2 Major tectonic features and distribution of mud volcanoes in the north Panama thrust belt (NPTB) superimposed on SeaMARC II bathymetry at $500 \mathrm{~m}$ contour interval. Mud volcanoes are differentiated into Types A, B, and C. Deformation front is located along northern extent of major thrust and oblique-trending faults. Major sediment transport systems are noted with arrows

Table 1. Core samples

\begin{tabular}{lcccc}
\hline Sample No. & Cruise ID & Location & Water depth $(\mathrm{m})$ & Sediment type \\
\hline 071061 & LDGO-RC09 & $10^{\circ} 11^{\prime} \mathrm{N} 77^{\circ} 13^{\prime} \mathrm{W}$ & 3191 & Clay, sand, marl \\
026025 & LDGO-RC12 & $10^{\circ} 43^{\prime} \mathrm{N} 79^{\circ} 04^{\prime} \mathrm{W}$ & 3537 & Clay, ooze \\
000008 & LDGO-VM15 & $10^{\circ} 11^{\prime} \mathrm{N} 78^{\circ} 30^{\prime} \mathrm{W}$ & 1798 & Silty chalk, ash \\
000009 & LDGO-VM15 & $9^{\circ} 46^{\prime} \mathrm{N} 79^{\circ} 38^{\prime} \mathrm{W}$ & 971 & Silty chalk \\
019013 & LDGO-VM20 & $9^{\circ} 24^{\prime} \mathrm{N} 77^{\circ} 21^{\prime} \mathrm{W}$ & 1739 & Foram marl, mud, sand \\
034034 & LDGO-VM24 & $10^{\circ} 40^{\prime} \mathrm{N} 79^{\circ} 06^{\prime} \mathrm{W}$ & 3539 & Clay, foram clay, ooze \\
03065005 & EXP 60-10 & $10^{\circ} 27^{\prime} \mathrm{N} 80^{\circ} 22^{\prime} \mathrm{W}$ & 3389 & Sandy silt \\
\hline
\end{tabular}




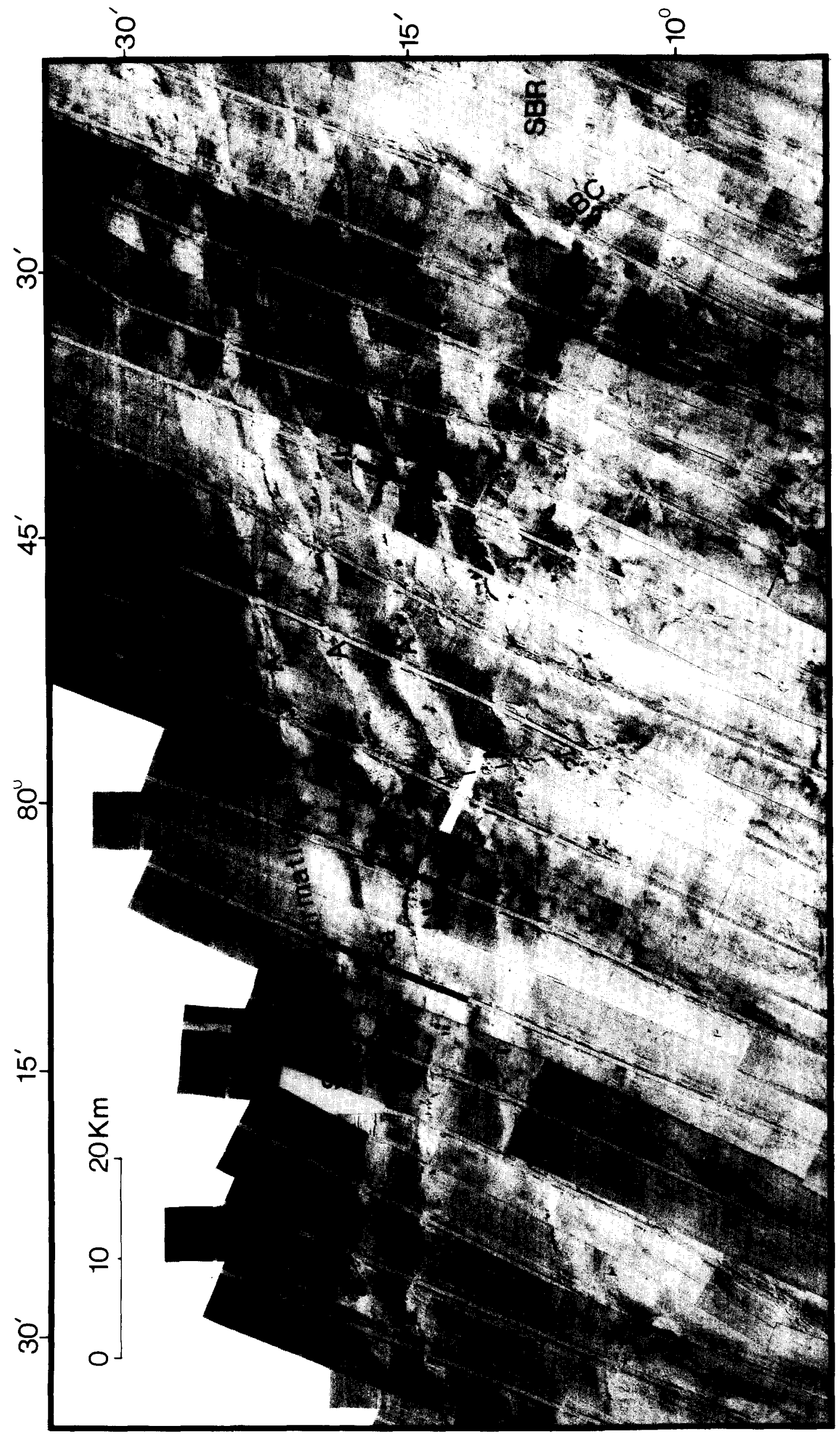

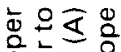

응 $\frac{\pi}{3}$

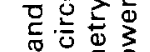

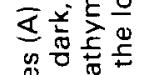

은즌

要造变

至

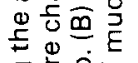

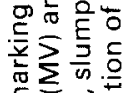

ह

का 0 응

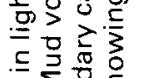

$3 \sum 5 \frac{5}{5}$

के

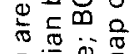

के है 흔

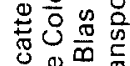

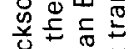

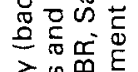

艾员心

흔 증

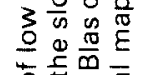

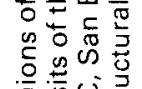

क्षे

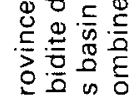

준

¿

政兽

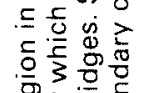

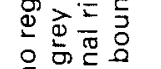

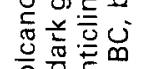

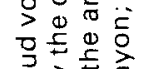

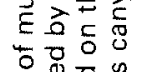

을 논

苋造》元

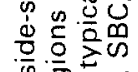

$=\Phi$

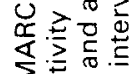

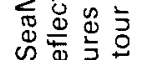

过它昰要

$m$ 穴而 $\varepsilon$

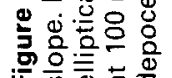



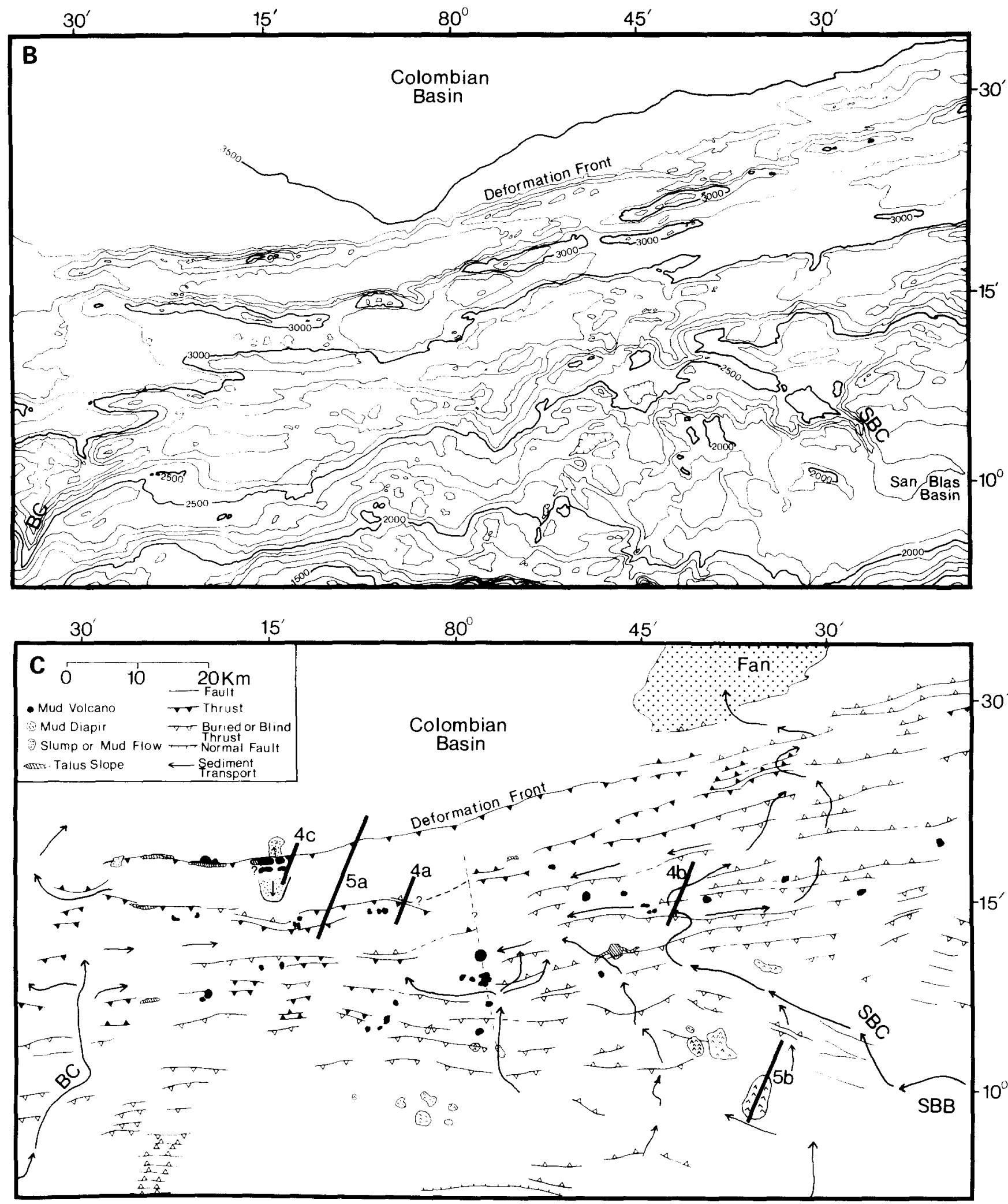

Figure 3 continued

the Late Neogene collision of the Panamanian arc with South America (Wadge and Burke, 1983). Silver et al. (1990) combined structural analyses of the NPTB with the relative plate motions of the Caribbean, Cocos and Nazca plates to estimate NNW-oriented Panama-Caribbean convergence at $1-15 \mathrm{~mm} / \mathrm{yr}$ (Figure I).

The western Colombian basin is underlain by relatively thick oceanic crust that is believed to be of Cretaceous age (Christofferson, 1976; Bowland and Rosencrantz, 1988). Sediment thicknesses in the basin, near the NPTB, vary between 1.5 and $>3.0$ s (two-way time) (Tagudin, 1988). Lu and McMillen (1982) subdivided the seismic stratigraphy of the western Colombian basin into fan-type deposits which abut the western and eastern edges of the NPTB and basin-type deposits which are located seaward of the central region. Bowland (1984) interpreted these units as being composed of mid-Tertiary to recent volcaniclastic and carbonate turbidites which overlie pelagic and hemipelagic deposits of probable late Cretaceous to early Tertiary age. 
Mud volcanoes offshore north Panama: D. L. Reed et al.

\section{Geological framework of the thrust belt}

SeaMARC II and digital reflection data provide an excellent image of nearly the entire thrust belt $\left(\sim 34700 \mathrm{~km}^{2}\right)$. The NPTB consists of three structural provinces (Figure 2): (1) an eastern province characterized by NW-trending thrust-bounded folds and two NNW-trending faults which cut obliquely across the thrust belt; (2) a central province composed of ENE-trending thrust-bounded folds; and (3) a western province where the thrust-bounded folds trend $\mathrm{NE}$ and the thrust belt is narrow, apparently associated with decreased convergence between western Panama and the Colombian Basin (Silver et al., 1990).

The central province, covering $\sim 17000 \mathrm{~km}^{2}$, consists of widely spaced $(7-8 \mathrm{~km})$ anticlinal ridges separated by slope basins. The central province can be subdivided into western and eastern regions, based on the direction of fold vergence (Tagudin, 1988), abundance of mud volcanoes. and presence of lower slope turbidite deposits. The western region of the central province (WCP in Figure 2) is dominantly composed of seaward-verging. thrust-bounded folds, many of which are capped by mud volcanoes (Figures 2 and $3 A$ ). The slope basins of the WCP contain thick turbidite deposits $(700-900 \mathrm{~m})$ which are ponded between the ridges.

In contrast, landward-verging folds with very few mud volcanoes characterize the eastern region of the central province (ECP in Figure 2). Turbidite deposition is sparse along the lower slope of the ECP as deposits drape over topographic features, typical of hemipelagic and pelagic sediments.

Slope basins in both the western and eastern provinces of the thrust belt are devoid of turbidites.
The western province contains two submarine canyons which allow detritus to bypass the lower slope, resulting in turbidite fans in the Colombian basin, seaward of the deformation front (Figure 2). The upper slope in the eastern province is composed of a $>250 \mathrm{~km}$-long ridge, hereafter called the San Blas ridge (Figure 2). The ridge acts as a barrier to sediment transport to the lower slope of the province, thereby restricting clastic deposition to the San Blas basin along the southern margin of the ridge. The basin contains $1-3 \mathrm{~km}$-thick turbidite sequences which are deformed and incorporated into the rear of the NPTB along several prominent backthrusts.

\section{Characteristics and distribution of mud volcanoes}

Side-scan images in the NPTB that may be related to mud volcanoes were assigned to three types $(A, B, C)$ according to the degree to which these features can be distinguished from slumps, rock outcrops, talus slopes, and debris flows. Type A exhibits the most well-defined features commonly associated with mud volcanoes, such as a circular to semi-circular shape (map view) high sonar reflectivity, positive bathymetric relief, and widths up to $2 \mathrm{~km}$ (Figures $3 A$ and $4 A$ ). The sea floor surrounding Type A mud volcanoes is relatively flat, typically formed by the broad crests of anticlinal ridges.

In contrast, Type B features are irregularly shaped, generally $<1 \mathrm{~km}$-wide, and commonly located along steep bathymetric slopes. The position along steep slopes, combined with the irregular shape, imply that some of the Type B features are probably related to slumping or rock outcrops rather than mud extrusion. Finally, Type C features differ markedly from Types A and $B$ by forming either highly irregularly-shaped
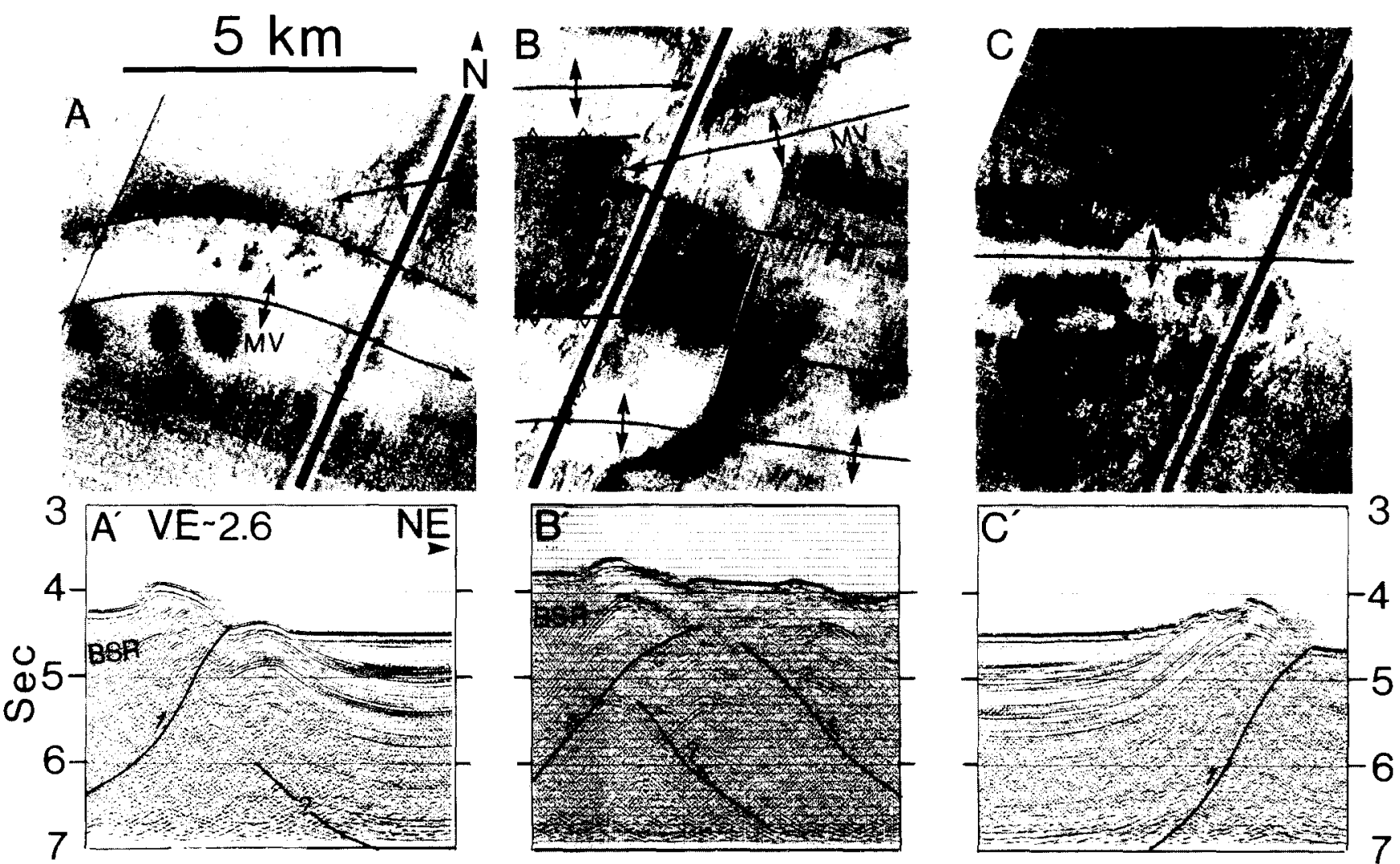

Figure 4 Side-scan image and migrated reflection profiles of mud volcanoes. $A-A^{\prime}$, Culmination of an anticline that is capped by three mud volcanoes. Note tight folding of anticline and bottom-simulating reflector (BSR) in hinge zone. B-B', Mud volcano along anticlinal ridge which deflects the San Blas canyon along the lower slope resulting in canyon bifurcation into two branches. $C-C^{\prime}$, Slumping or mud volcano along limbs of seaward-verging anticline along deformation front 
regions along the sides of canyons or the bases of prominent scarps. Type $\mathrm{C}$ features are most likely associated with slump deposits or scars, slope gullies, and talus along fault scarps.

We chose to limit our analysis to Type A features (e.g. Figure $4 A$ ), because their well defined sonar image is the most characteristic of mud volcanism. The inclusion of Types $\mathrm{B}$ and $\mathrm{C}$ does not alter the principal findings of our study. A total of 44 Type A mud volcanoes were identified as highly reflective, circular to slightly elliptical features (Figures 2 and $3 A$ ). The mud volcanoes vary in width $(0.4-2.0 \mathrm{~km})$ and are $<100 \mathrm{~m}$ high, as suggested by the lack of closure of consecutive $50 \mathrm{~m}$ isobaths on SeaMARC bathymetry. The mud volcanoes occur as solitary features or clustered in groups, composed of as many as six volcanoes.

The highest concentration of mud volcanoes is located along the lower slope in the western region of the central province (WCP in Figure 2). Thirty-two of the mud volcanoes, or $73 \%$ of the total, are located in the $-2400 \mathrm{~km}^{2}$ region which composes $7 \%$ of the thrust belt area. Twenty-six of the mud volcanoes are located along structural culminations in the anticlinal ridges, especially along the more tightly folded anticlines (Figure 4). Three of the mud volcanoes are aligned along a NNW trend which may delineate an oblique-trending fault (Figure $3 C$ )

Mud volcanoes were not observed seaward of the deformation front, in contrast to observations in other accretionary prisms (Westbrook and Smith, 1983; Breen et al., 1988; Langseth et al., 1988). In fact, very few mud volcanoes are located at the deformation front and these are restricted to a small region that has been modified by gravitational slope failure (Figures 3 and $4 C$ ). Either mud volcanism or slope failure could be responsible for these features and the two processes may be related. For example, deformation and fluid migration associated with mud eruptions may result in slope failure. This region forms the steepest slope along the frontal fold and thus gravitational failure might be expected. Conversely, a rapid decrease in overburden following slumping may stimulate the ascent of overpressured sediments in the underlying strata, analogous to the catastrophic rock slide which triggered the lateral blast of the 18 May 1980 volcanic eruption at Mount St Helens (Voight et al., 1981). Approximately $8 \mathrm{~km}$ west of this region, two mud volcanoes are located along the frontal thrust, representing the only such occurrence in the NPTB (Figure 3A).

Type A mud volcanoes, outside of the WCP, are scattered and represent a small proportion $(27 \%)$ of the total within the NPTB. Many of these features are located in the mid-slope area of the central province, slightly east of the Type A concentration in the WCP and near oblique-trending faults in the eastern province (Figure 2). The underlying structural and stratigraphic framework in these regions is complicated and poorly imaged by our data. However, the mud volcanoes exhibit several characteristics that can be distinguished from those of the WCP. The mud volcanoes are highly variable in width in the mid-slope region, and generally smaller $(<1.0 \mathrm{~km}$-wide $)$. The small size precludes assignment of a particular shape or height to these features and may reflect partial burial by sediments in some regions. Direct observations of the sea floor are necessary to test this possibility.
Several mud volcanoes are located near the oblique-trending faults which cross the thrust belt in the eastern province. The mud volcanoes are elongated, lacking the characteristic circular shape (map view) of the mud volcanoes elsewhere in the thrust belt. Silver et al. (1990) interpreted these faults as right-lateral shears associated with oblique convergence in the eastern province. Mud volcanoes have been previously reported along strike-slip faults in other regions of compressive deformation (e.g. Ridd, 1970; Brown and Westbrook, 1988).

\section{Lower slope depocentre of the central province}

The large majority of mud volcanoes are located in the major sediment depocentre along the lower slope of the NP'TB. The depocentre is formed by the merging of the two major sediment transport systems in the WCP (Figure 2). One of the systems is composed of a linear canyon (BC in Figure $3 B$ ) along the western edge of the depocentre which transports detritus directly to the Colombian basin, bypassing much of the lower slope. Core sample 03065005 near the associated fan deposit contains sand and silt-sized detritus (Table 1, Figure 2). Because of the curvature of the deformation front in this region, the southeastern margin of the sedimentary deposit extends eastward into the lower slope depocentre. The depocentre is, however, fed primarily by a canyon system which extends downslope from the western edge of the San Blas basin. The configuration of this transport system results in the stepwise partitioning of detritus into three interconnected depocentres: (1) the San Blas basin along the upper slope of the eastern province; (2) the lower slope depocentre; and (3) the Colombian basin seaward of the central province (Figure 2). The depocentres are linked by channels and canyons which extend laterally along the thrust belt from the eastern Panama shelf in the Gulf of Uraba to the floor of the Colombian basin, a total distance of $\sim 350 \mathrm{~km}$.

The configuration of the transport system is critical to the development of sedimentary deposits in the region of the mud volcanoes and in the Colombian basin, seaward of the mud volcano region. The system acts as a funnel concentrating detritus derived from the eastern and central regions of northern Panama, a mountainous terrane covering $\sim 15000 \mathrm{~km}^{2}$, into the WCP of the thrust belt. The upper portion of the system consists of a $5 \mathrm{~km}$-wide canyon which extends from the eastern Panama shelf to the eastern San Blas basin. The canyon connects with a $>250 \mathrm{~km}$ long channel which runs along the axis of the San Blas basin. The axial channel receives additional detritus from numerous canyons which extend down from the upper slope. The channel bends around the San Blas ridge at the western edge of the San Blas basin and extends downslope along the San Blas submarine canyon (Figures 2 and 3). The canyon bifurcates into several channels which meander through the lower slope of the WCP, feeding the slope basins which compose the depocentre. The main channel breaches the frontal fold and terminates in a turbidite fan in the Colombian basin, seaward of the deformation front (Figures 2 and $3 C$ ). The slope basins contain $0.4-0.8$ s thick turbidite sequences which lap onto the southern limbs of the thrust-bounded anticlines (Figures $4 C$ and $5 A$ ). The anticlines are composed of folded basinal turbidites, 
originally deposited in the Colombian basin ( $\mathrm{Lu}$ and McMillen, 1982). It is noteworthy that the depocentre represents the only significant collection of clastic (?) turbidites along the lower slope of the NPTB and that these deposits coincide with the highest concentration of mud volcanoes.

The relationship of sonar reflectivity (backscattering) to sediment facies is complicated as both slope angle and sea floor roughness affect reflectivity, as well as sub-bottom $(<1 \mathrm{~m})$ sediment layers (Lee et al., 1988). Long range sonar studies, however, have shown that low sonar reflectivity can correspond to fine-grained sediments in abyssal settings, whereas regions of high reflectivity characterize sand-and silt-bearing deposits (e.g. Kidd et al., 1985). The low reflectivity regions of the NPTB are located along the anticlinal ridges whereas the San Blas basin and the slope basins of the lower slope depocentre are marked by high reflectivity regions. Sedimentological data are sparse and widely spaced in the NPTB (Figure 2), although seven piston cores (Table l) suggest that the moderate to high reflectivity regions correspond to sand- and silt-bearing deposits. Low reflectivity regions mark clay- and ooze-bearing sediments. Furthermore, the main sediment transport system exhibits a progressive decrease in reflectivity from the San Blas basin, to the lower slope depocentre, and finally to the fan complex seaward of the deformation front.

\section{Discussion}

Mud volcanoes form in a variety of tectonic environments. For example, mud volcanoes along the passive continental margin in the Gulf of Mexico are remarkably similar to those in the NPTB (see Figure 12 in Hedberg, 1980). Consequently, a variety of processes operating alone or in concert, may result in the ascent and extrusion of the low density muds. The association of mud volcanoes with regions of overpressure is, however, a common observation in many regions (Hedberg, 1974, 1980; Fertl, 1976; Westbrook and Smith, 1983).

One of the best studied examples of mud volcanoes associated with compressional tectonics is the accretionary prism of the Barbados Ridge Complex (Stride et al. 1982). The mud volcanoes in this region are located both within and seaward of the accretionary prism. Most of the mud volcanoes are located in the southern portion of the prism which is marked by the accretion of the Orinoco fan complex. Westbrook and Smith (1983) attributed the seaward volcanoes to loading by the prism and hydrofracturing along a proto-décollement. Langseth et al. (1988) suggested that fluid migration leading to the development of the seaward mud volcanoes is also influenced by a ridge in the underlying oceanic basement. Brown and Westbrook (1988) observed that mud volcanoes within the prism commonly overlie reverse faults and mark regions of subcretion (underplating).

The distribution of mud volcanoes in the NPTB differs from the Barbados Ridge Complex in several important ways. (1) The accreted strata in the volcano-rich WCP consist largely of basinal turbidites (Lu and McMillen, 1982). In contrast, the regions of accreted fan deposits in the western and eastern provinces exhibit very few mud volcanoes (Figure 2). (2) Mud volcanoes were not observed seaward of the
NPTB deformation front (Figures 2 and 3 A). (3) There is no evidence of structures in the oceanic basement seaward of the WCP which would correspond to the distribution of mud volcanoes (Bowland and Rosencrantz, 1988; Tagudin, 1988). (4) The majority of mud volcanoes are located along the crests of thrust-bounded anticlines, not along reverse faults exposed on the sea floor. (5) The mud volcanoes do not appear to coincide with regions of subcretion, at least along the lower slope. The absence of subcretion is especially evident where mud volcanoes occupy the crests of the frontal fold and the next fold landward (Figures $4 C$ and $5 A$ ). The upper slope of the NPTB exhibits few mud volcanoes, although subcretion may be active in this region. Mud diapirs, however, were observed along the upper slope (Figure 5B) (Vitali et al., 1985).

Breen et al. (1988) suggested that mud layers in the vicinity of the decollement are the stratigraphic source of the mud volcanoes in the NPTB. Unfortunately, the source horizon can not be accurately determined from the existing data, partly because no reflection profile passes directly over a mud volcano. A combination of processes, such as described below, may be the driving force of mud volcanoes in the NPTB or combine with diapirism and folding as envisioned by Breen ot al. (1988).

\section{Sediment loading, methane generation and gas hydrate?}

High sedimentation rates seaward of the deformation front are a contributing factor to the development of high pore fluid pressure in the Barbados Ridge Complex (Shi and Wang, 1985). High sedimentation rates alone, however, may not account for NPTB mud volcanoes. The thickest sedimentary deposits and, presumably, highest sedimentation rates, are located in the San Blas basin and the major fan complexes seaward of the deformation front in the western and eastern provinces (Figure 2). Very few mud volcanoes were observed in these regions or within the thrust belt, landward of these regions.

The fact that the majority of the NPTB mud volcanoes are located in the lower slope depocentre suggests that these deposits have influenced mud volcano development. The relative timing of sedimentation in the depocentre and the formation of the mud volcanoes can be inferred from seismic stratigraphic relations. Folding of the Colombian basin strata along the deformation front has produced a series of anticlinal ridges that divide the depocentre into several slope basins (Figures 2 and $5 A$ ). In some regions, the ridges may contain diapiric mud intrusions which may have developed in response to folding above the decollement (Breen et al. 1988). Growth folding in the slope basin strata indicates that turbidite deposition was contemporaneous with folding (Figures 4 and $5 A$ ). The location of nearly all of the mud volcanoes along anticlinal ridges landward of the deformation front, rather than along the deformation front itself, suggests that volcano formation followed fold nucleation. Therefore, we infer that thrusting and folding along the deformation front developed concurrently with the deposition of slope basin turbidites, and that mud volcanism followed thereafter.

The onset of slope deposition prior to volcanism suggests a possible cause and effect relationship. The 


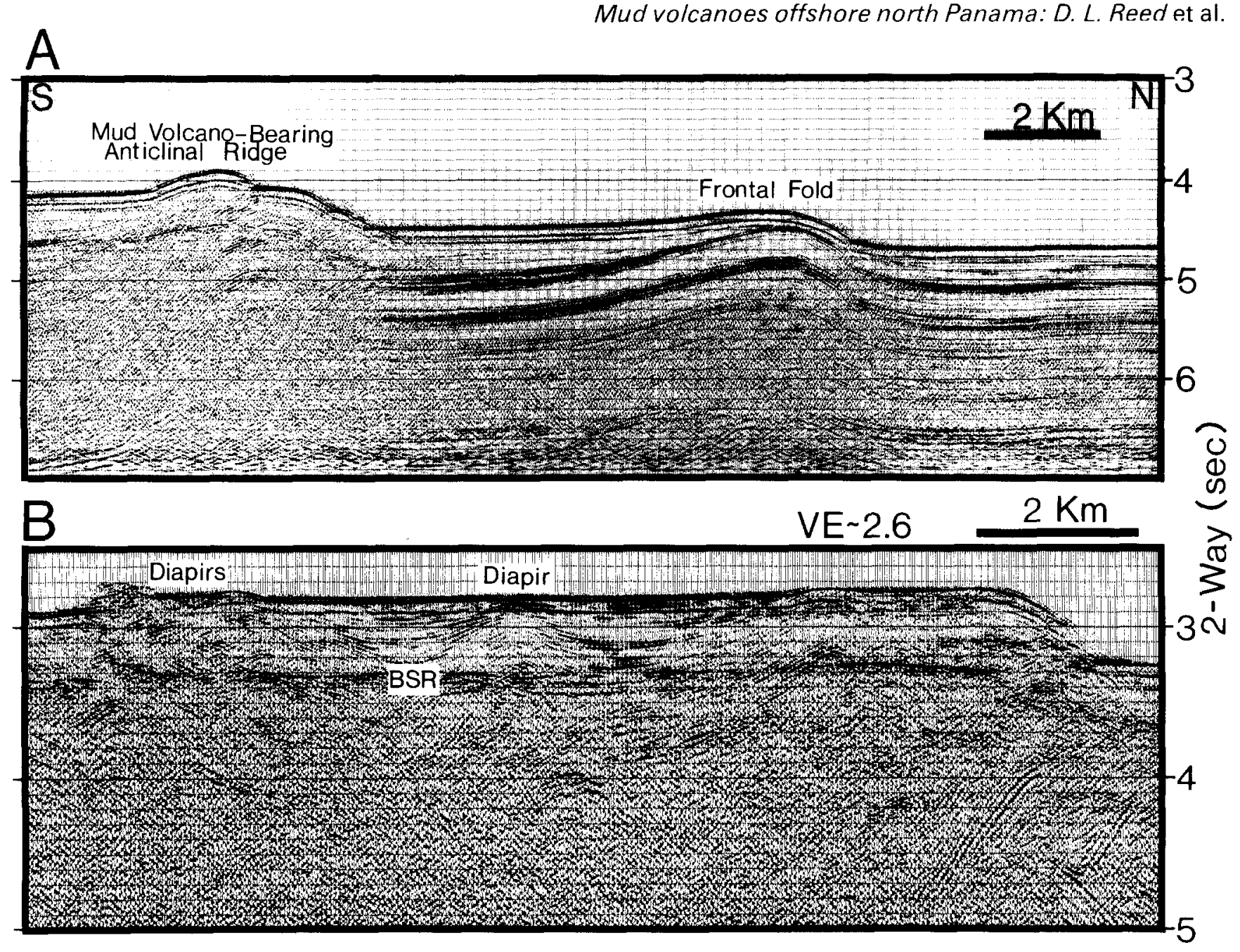

Figure 5 (A) Migrated seismic line showing seaward-verging fold and position of mud volcano-bearing anticlinal ridges in lower slope depocentre. Note BSR in the mud volcano-bearing anticlinal ridge. Location given in Figure $3 A$. (B) Migrated seismic line showing of diapiric structures and BSR along upper slope of the NPTB. Location given in Figure $3 A$

sedimentary deposits of the lower slope depocentro may assist in the development of overpressure, resulting in mud volcanism, through differential loading and the generation and accumulation of methane gas. Loading by the slope basin strata produces a fluid pressure gradient between the slope basins and the hinge zones of the anticlinal ridges. Magara (1986) showed that fluid flow is directed towards the hinge zones in response to such a gradient and will be stratigraphically controlled at moderate depths by the formation of pressure seals within shale layers. such as contained in turbidite sequences. The difference in hydraulic head (sum of the elevation head and pressure head) along a stratigraphic horizon beneath the slope basin deposits and the same horizon in the fold hinge is one measure of the pressurc gradient (Freeze and Cherry, 1979). For example, a simple depth conversion of the anticlinal ridge and basin couple in Figlre $4 C\left(V_{\text {water }}=1500 \mathrm{~m} / \mathrm{s}, V_{\text {scit }}=\right.$ $2000 \mathrm{~m} / \mathrm{s}$ ). shows that a layer located in the fold hinge is buried by an additional $700 \mathrm{~m}$ of sediment and $300 \mathrm{~m}$ of sea water in the region of the slope basin. There is no difference in hydraulic head between the regions under hydrostatic conditions. However, if lithostatic conditions prevail, then the pressure head (and hydraulic head) for a layer under the slope basin will increase by $\sim 700 \mathrm{~m}$ (assuming $\rho_{\text {water }}=1 \mathrm{~g} / \mathrm{ml}, \rho_{\mathrm{sed}}=$ $2 \mathrm{~g} / \mathrm{ml}$ ). Therefore, a strong pressure gradient resulting from the difference in hydraulic head will develop under lithostatic conditions with the associated fluid flow in the direction of the hinge zones (Figure 6). Tectonic loading by the stacking of seaward-verging thrust sheets may also contribute to the fluid pressure gradient in the depocentre.

Methane generation and migration provides another mechanism for the development of overpressure (Hedberg, 1974; Spencer, 1987). Indeed, mud volcanoes throughout the world are associated with abundant release of methane gas (Hedberg. 1980). Methane accumulations and venting have been documented in several compressional settings, including the Barbados Ridge complex (Moore et al., 1988), Nankai trough (LePichon et al., 1987) and the Oregon-Washington accretionary prism (Ritger et al. 1987). Brown and Westbrook (1988) suggested a secondary role for methane in the formation of mud volcanoes along the Barbados Ridge complex.

Evidence of methane in the NPTB includes the widespread presence of a bottom-stimulating reflector (BSR) in seismic profiles (Figure's 4 and 5A) (Lu and McMillen, 1982). BSRs are produced by an impedance contrast between gas (methane) hydrate and underlying sediments which, in some cases. contain gas as a free phase (Bryan, 1974: Shipley et al. . 1979). Gas hydrate is an ice-like compound that traps methane in the crystal lattice (Kvenholden and Barnard, 1982) and decreases the permeability of the host sediment (deBoer et al. . 1985). The BSR has not been directly 

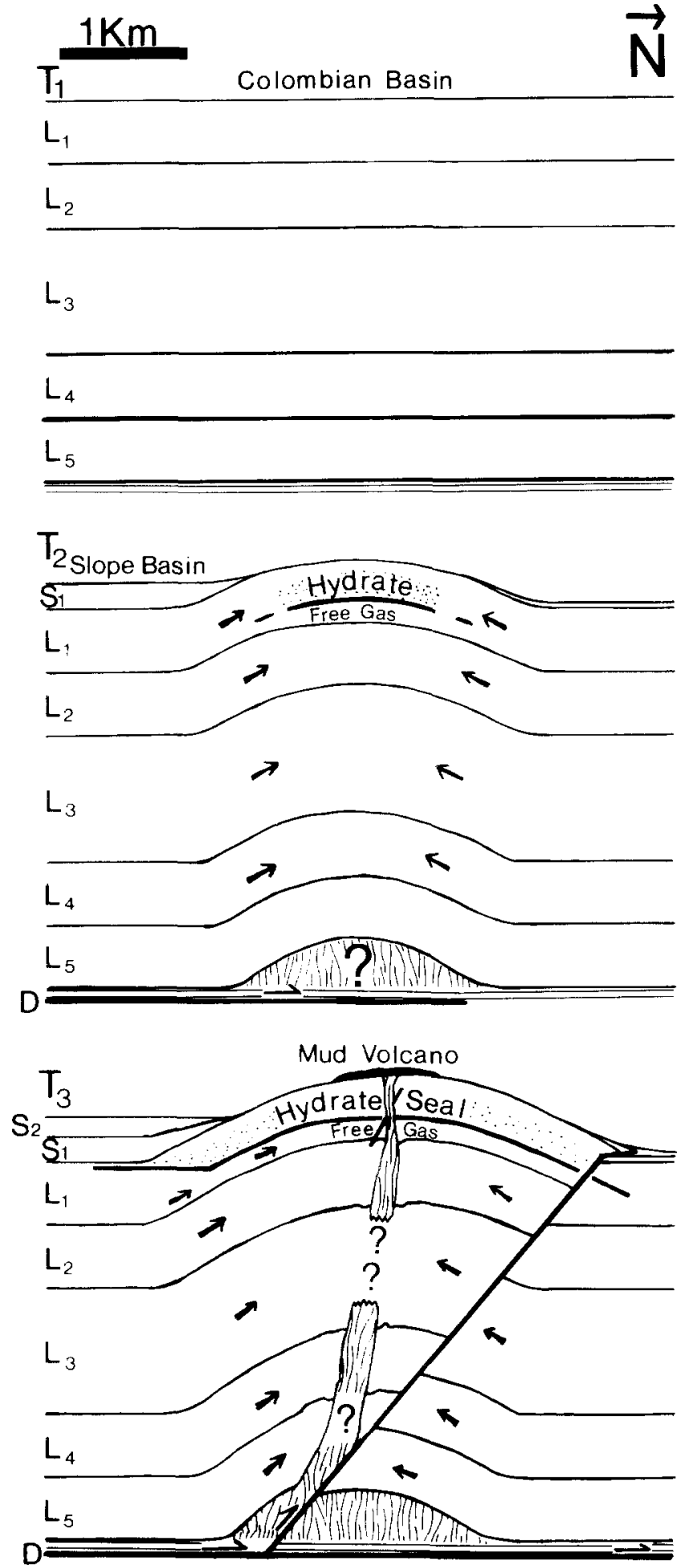

Figure 6 Schematic model of folding, thrust faulting and sedimentation along the deformation front. Folding may be accompanied by mud diapirism. Folding results in the up-dip migration of methane and methane-saturated pore fluids (arrows) along the fold limbs at time $T_{2}$. Fluid migration is assisted by the loading of sediments in slope basin, landward of the frontal fold. Methane accumulation in the hinge zone forms a hydrate seal which traps methane in underlying strata. Seal rupture allows escape of methane, fluid and mud from both within and beneath the hydrate, thus stimulating mud volcanism at time $T_{3}$

sampled in the NPTB. However, biogenic methane is abundant in Pliocene turbidites of the Colombian basin and the more deeply buried rocks in the basin are thermally mature, leading to generation of additional methane (Finley and Krason, 1987). Sub-bottom depth (two-way time) to the BSR in the NPTB increases with increasing water depth and the reflection polarity is reversed (T. H. Shipley, unpublished data), typical of gas hydrates.

The BSR is commonly observed within the anticlinal ridges (Figures $4 A$ and $5 B$ ), particularly those landward of the frontal fold. The very low permeability of the hydrate provides an effective seal for trapping methane gas in the hinge zone (deBoer et al. . 1985). In addition, the hemipelagic sediments which drape the anticlinal ridges may be less permeable than the underlying turbidites, thus contributing to the formation of a lithologic seal. The range of $P-T$ conditions $\left(\sim 13-18^{\circ} \mathrm{C} ; \sim 350-500\right.$ bars), estimated for the base of the hydrate in the anticlines, is compatible with methane existing as free gas, dissolved in pore fluid or both.

Although the BSR is widespread along northern Panama, the combination of deformation, sediment loading, and the amount of methane may vary from one region to another, the latter in accordance with the volume of clastic sediments, content of organic carbon in these sediments, degree of methane generation, and the development of suitable migration paths and reservoirs for methane accumulation. Unfortunately, it is not possible to determine the sedimentological characteristics of the depocentre without additional core samples. However, the depocentre contains the largest volume of clastic turbidite deposits along the lower slope of the thrust belt and that, in itself, may provide an additional source for methane as compared to other regions of the NPTB.

We suggest that folding along the deformation front stimulates the up-dip migration of methane and methane-saturated pore fluids into the hinge zones of the anticlinal ridges (Figure 6). Density-driven migration of methane may be enhanced by fluid flow related to loading by the slope basin turbidite sequences. Vertical diffusion of the methane in the hinge zones is slowed by the cap of hemipelagic sediments, resulting in increased methane concentrations which are a necessary condition for hydrate development under favourable $P-T$ conditions (Kvenholden and Barnard, 1982: deBoer et al., 1985).

\section{Triggering mechanism for mud eruptions}

Hydrate formation increases the strength and cohesion, and decreases the permeability within the host sediment (deBoer et al., 1985). Buoyancy forces will promote methane migration towards the hinge zone, resulting in the displacement of pore fluids beneath the hydrate. The sub-hydrate accumulation of methane will increase pore fluid pressure, already elevated by regional tectonic and loading phenomena. Methane and methane-saturated pore fluids also decrease the bulk density of the sediments beneath the seal, thus providing a buoyancy force for diapirism and mud volcanism if the seal is ruptured (Hedberg, 1974).

The sediments which are extruded by a mud volcano must either pass through the zone of hydrate or be derived from within it (Figure 6). Hence the rupture of the hydrate seal provides a critical event in the evolution of the sediment which is ultimately extruded at the sea floor. Thinning and weakening of the seal by deformation or changes in $P-T$ conditions may act to trigger eruptions. Unfortunately. our migrated reflection profiles do not image the detailed structural relations in the mud volcanoes. Possible causes of seal 
Mud volcanoes offshore north Panama: D. L. Reed et al.

rupture include faulting along the tops of the anticlines, fracturing ahead of ascending diapirs, and hydrofracturing. Hydrofractures will develop if pore fluid pressures are large enough to exceed confining pressures in the hinge zone (Magara, 1986).

A change in $P-T$ conditions, such as a reduction in pressure or increase in temperature, can also result in hydrate weakening and decomposition. Processes that may perturb $P-T$ conditions include removal of overburden by slumping and thus reducing confining pressure and the introduction of warm pore fluids migrating upward along fold limbs, faults, or hydrofractures. Hydrate decomposition releases large quantities of methane, resulting in a 170-fold increase in the volume of pore fluids (including free gas) at 1 atmosphere (Kvenholden and Barnard, 1982). The volumetric increase will be much less at the pressures associated with depth of the hydrate in the NPTB, because of the compressibility of methane. Even so, the released methane will displace pore fluids and increase pore fluid pressures, if permeability of the host sediment is low. Once the seal is ruptured, pore fluid pressures will decrease leading to the rapid expansion of methane which, in turn, may account for the violent eruptions which characterize many mud volcanoes (Hedberg, 1980).

\section{Distribution of mud volcanoes and vergence}

The mud volcano-rich WCP differs from the mud volcano-poor ECP in two important ways: (1) the slope basin deposits are substantially thicker in the WCP and (2) seaward verging thrusts are common in the WCP whereas landward verging thrusts characterize structures in the ECP (Tagudin, 1988). Landward vergence is commonly believed to be evidence of low shear stress, and high pore fluid pressure. along the décollement (Seely, 1977). Likewise. mud volcanoes are commonly associated with regions of high pore fluid pressure (Westbrook and Smith. 1983). Therefore. mud volcanoes might be expected to predominate in the regions of landward-vergence. such as the ECP. The opposite relationship is observed in the NPTB, however. We present several hypotheses for this enigma. First, vergence and mud volcanism may reflect processes operating at different depths, such that vergence is controlled by conditions at the base of the thrust belt whereas the mud volcanoes may be driven by processes at shallow depth within the lower slope depocentre. Tagudin (1988) correlated the distribution of landward verging folds with the lateral extent of a mid-Tertiary (?) seismic stratigraphic sequence in the vicinity of the décollement. Second, the frontal fold in the WCP does not display a sense of vergence during the early stages of deformation (Breen et al., 1988). consistent with the concept of low shear stress along the décollement (Seely, 1977). The gentle sea floor slope $\left(1-2^{\circ}\right)$ in the central province also suggests low shear stress along the décollement, based on the concept of wedge taper (Breen et al., 1988: Davis et al., 1983). Fluid venting by mud volcanoes, shortly after fold nucleation, may increase shear stress by reducing pore fluid pressure. and hence promote the development of seawardverging thrusts. Third. slope basin deposits of the WCP are ponded landward of the anticlinal ridges, resulting in increased compaction or pore fluid pressure along the south-dipping limb as compared to the north-dipping limb. Loading by the slope basin deposits results in pore fluid flow along the south-dipping limb of the frontal fold. Fluid flow and differential compaction along this limb may form a south-dipping anisotropy which could influence the geometry of the incipient thrust.

\section{Conclusions}

Mud volcanoes are concentrated along thrust-bounded anticlinal ridges in the only lower slope depocentre in the NPTB. The depocentre consists of several slope basins containing thick turbidite deposits. Differential loading caused by the slope basin deposits, combined with the generation and migration of methane, may contribute to the development of high pore-fluid pressure in the adjacent anticlinal ridges. Methane accumulation in the hinge zones of the ridges has resulted in the formation of gas hydrate. The hydrate is capable of forming a seal that can trap additional methane which will promote the development of high pore fluid pressure. Thus several processes may combine to provide an overpressured environment leading to mud volcanism in the lower slope depocentre.

The stratigraphic source of the mud volcanoes is poorly constrained at present. although the erupted sediments must pass through the hydrate zone, or be derived from within it, prior to breaching the sea floor. Hence, rupture of the hydrate caused by faulting, hydrofracturing or a perturbation in $P-T$ conditions may provide a triggering mechanism for the mud eruptions and result in the release of additional methane which will add to the energy of the eruption. The combination of sediment loading and methane generation may result in the development of the mud volcanoes or contribute to the evolution of diapiric muds emanating from the vicinity of the décollement.

\section{Acknowledgements}

This research was supported by NSF grants to E. Silver, G. Moore and T. Shipley. We thank Greg Moore for providing the seismic processing facility at the University of Tulsa, helpful discussions, and review of an early draft. Don Hussong, Karen Mansfield and the crew of the R/V Moana Wave of the Hawaii Institute of Geophysics were instrumental in data acquisition and post-cruise SeaMARC II processing. We thank Peggy Delaney, Kevin Brown, Keith Kvenholden, Darla Heil. Nancy Breen, Danny Orange, Dennis Wuthrich and Casey Moore for helpful discussions. We also thank two anonymous reviewers for their helpful comments.

\section{References}

Barber, A. J., Tjokrosapoetro, S. R. and Charleton, T. R. (1986) Mud volcanoes, shale diapirs, wrench faults, and melanges in accretionary complexes, eastern Indonesia, AAPG Bu/l. 70, $1729-1741$

Bowin, C. L. (1976) Caribbean gravity field and plate tectonics, Geol. Soc. Am. Spec. Paper 169, 79

Bowland, C. L. (1984) Seismic stratigraphy and structure of the western Colombian basin, Caribbean Sea: MSC thesis, Austin, University of Texas, $248 \mathrm{pp}$.

Bowland, C. L. and Rosencrantz, E. (1988) Upper crustal structure of the western Colombian Basin, Caribbean Sea, Geol. Soc. Am. Bull. 100, 534-546 
Breen, N. A., Silver, E. A. and Hussong, D. M. (1986) Structural styles of an accretionary wedge south of the island of Sumba, Indonesia, revealed by SeaMARC II side-scan sonar, Geol. Soc. Am. Bull. 97, 1250-1261

Breen, N. A., Tagudin, J. E., Reed, D. L., Silver, E. A. (1988) Mud-cored parallel folds and possible melange development in the North Panama thrust belt, Geology 16, 207-210

Brown, K. M. and Westbrook, G. K. (1988) Mud diapirism and subcretion in the Barbados ridge accretionary complex: the role of fluids in accretionary processes, Tectonics 7,613-640

Bryan, G. M. (1974) /n situ indications of gas hydrate, in: Natural Gases in Marine Sediments (Ed. I. R. Kaplan), Plenum Press, New York, p. 299-308

Case, J. E. and Holcombe, T. L. (1980) Geologic-tectonic map of the Caribbean region, US Geological Survey, Misc. Invest. Map, $1-1100$

Christofferson, E. (1976) Colombia basin magnetism and Caribbean region, Geol. Soc. Am. Bull. 87, 1255-1258

Davis, D., Suppe, J. and Dahlen, F. A. (1983) Mechanics of fold-and-thrust belts and accretionary wedges, J. Geophys. Res. 88, 1153-1172

deBoer, R. B., Houbolt, J. J. and Lagrand, J. (1985) Formation of gas hydrates in permeable medium, Geo-Marine Lett. 3, 245-249

Fertl, W. H. (1976) Abnormal Formation Pressures, Elsevier, New York, $382 \mathrm{pp}$.

Finley, P. D. and Krason, J. (1987) Basin analysis, formation and stability of gas hydrates in the Colombia Basin: Geological evolution and analysis of confirmed or suspected gas hydrate localities (Abstract), AAPG Bull. 71, 555-556

Freeze, R. A. and Cherry, J. A. (1979) Groundwater, Prentice-Hall, Englewood Cliffs, NJ, $604 \mathrm{pp}$.

Hedberg, H. (1974) Relation of methane generation to undercompacted shales, shale diapirs, and mud volcanoes, AAPG Bull. 58, 661-673

Hedberg, H. D. (1980) Methane generation and petroleum migration in: Problems of Petroleum Migration (Eds. W. H. Roberts III and R. J. Cordell), AAPG Studies in Geology 10, 179-206

Higgins, G. E. and Saunders, J. B. (1967) Report on 1964 Chatham mud island, Erin Bay, Trinidad, West Indies, AAPG Bull. 51, 55-64

Kidd, R. B., Simm, R. W. and Searle, R. C. (1985) Sonar acoustic facies and sediment distribution on an area of the deep ocean floor, Marine and Petrol. Geol. 2, 210-221

Kvenholden, K. A. and Barnard, L. A. (1982) Hydrates of natural gas in continental margins, in: Studies in Continental Margin Geology (Eds. J. S. Watkins and C. L. Drake) AAPG Memoir 34, 631-640

Langseth, M. G., Westbrook, G. K. and Hobart, M. A. (1988) Geophysical survey of a mud volcano seaward of the Barbados Ridge accretionary complex, J. Geophys. Res. 93, $1049-1061$

Lee, H. J., Edwards, B. D., Kayen, R. E., Field, M. E., Gardner, J. V. and Kenyon, N. H. (1988) Factors controlling long-range side-scan returns, as determined from the distal depositional lobe of Monterey fan, California, Geol. Soc. Am. Ann. Meeting Abstracts with Programs 20, A129

LePichon, X., Ligamce, T., Boulegue, J., Charret, J., Faure, M. Kano, K., Lallemant, S., Okada, H., Rangin, C., Taira, A., Urabe, T. and Uyeda, S. (1987) Nankai trough and Zenisu ridge: a deep-sea submersible survey, Earth Planet. Sci. Lett. 83, $285-299$
Lu, R. S. and McMillen, K. J. (1982) Multichannel seismic survey of the Colombian Basin and adjacent margins, in: Studies in Continental Margin Geology (Eds. J. S. Watkins and C. L. Drake) AAPG Memoir 34, 395-410

Magara, K. (1986) Geological Models of Petroleum Entrapment, Elsevier Applied Science, New York, 322 pp.

Moore, J. C., Mascle, A. et al. (1988) Tectonics and geohydrology of the northern Barbados Ridge: results from Ocean Drilling Program Leg 110, Geol. Soc. Am. Bull. 100, 1578-1593

Ridd, M. F. (1970) Mud volcanoes in New Zealand, AAPG Bull. $54,601-616$

Ritger, S., Carson, B. and Suess, E. (1987) Methane-derived authigenic carbonates formed by subduction-induced pore water expulsion along the Oregon/Washington margin, Geol. Soc. Am. Bull. 98, 147-156

Seely, D. R. (1977) The significance of landward vergence and oblique structural trends on trench inner slopes, in: /s/and Arcs, Deep Sea Trenches and Back-Arc Basins (Eds. M. Talwani and W. C. Pitman, III) Am. Geophys. Union, 187-198

Shepard, F. P. (1973) Sea floor off Magdalena delta and Santa Marta Area, Colombia, Geol. Soc. Am. Bull. 84, 1955-1972

Shi, Y, and Wang, C. (1985) High pore pressure generation in sediments in front of the Barbados Ridge complex, Geophys. Res. Lett. 12, 773-776

Shipley, T. H., Houston, M. H. et al. (1979) Seismic evidence for widespread possible gas hydrate horizons on continental slopes and rises, AAPG Bull. 63, 2204-2213

Silver, E. A., Reed, D. L., Tagudin, J. E. and Heil, D. J. (1990) Implications of the north and south Panama thrust belts for the origin of the Panama orocline, Tectonics, in press

Spencer, C. W. (1987) Hydrocarbon generation as a mechanism for overpressuring in the Rocky Mountain region, AAPG Bull. $71,368-388$

Stride, A. H., Belderson, R. H. and Kenyon, N. H. (1982) Structural grain, mud volcanoes and other features on the Barbados ridge complex revealed by Gloria long range side-scan sonar, Mar. Geol. 49, 187-196

Tagudin, J. E. (1988) A correlation between fault vergence, fault spacing and sediment type in the North Panama thrust belt, MSc thesis, Santa Cruz, University of California, $73 \mathrm{pp}$.

Vitali, C., Mauffret, A., Kenyon, N. and Renard, V. (1985) Panamanian and Colombian deformed belts: an integrated study using GLORIA and Seabeam transits and seismic profiles in: Geodynamique des Caraibes (Ed. A. Mascle), Symposium Paris February 1985, Editions Technip., Paris, $451-461$

Voight, B., Glicken, H., Janda, R. J. and Douglas, P.M. (1981) Catastrophic rockslide avalanche of May 18, in: The 1980 Eruptions of Mount St Helens, Washington (Eds. P. W. Lipman and D. R. Mullineaux), US Geological Survey Professional Paper 1250, 347-378

Wadge, G. and Burke, K. (1983) Neogene Caribbean plate rotation and associated Central American tectonic evolution, Tectonics 2, 633-643

Westbrook, G. K. and Smith, M. J. (1983) Long decollements and mud volcanoes: evidence from the Barbados Ridge complex for the role of high pore fluid pressure in the development of accretionary complex, Geology 11,279-283

Williams, P. R., Pigram, C. J. and Dow, D. B. (1984) Melange production and the importance of shale diapirism in accretionary terrains, Nature $309,145-146$ 